\title{
NEISTOTY V POVODŇOVOM MODELOVANÍ
}

\author{
Matej Vojtek
}

\begin{abstract}
In recent years, several legally binding and non-binding documents related to flood protection with a specific emphasis on producing flood maps were adopted by the EU. Flood modeling is an important part of flood risk analysis since it results in showing the flood depth, flood extent, and water flow. However, flood modeling incorporates several uncertainties which influence the resulting flood maps. Therefore, the aim of this article is to point out and describe these uncertainties which are related to the application of hydrologic-hydraulic models and their input data. The main sources of uncertainty in model input data arise from the digital elevation model, roughness parameters, cross-section spacing, geometric data, and hydraulic structures along the reach. Another source of uncertainty is the estimation of design discharges with T-year return periods or design hydrographs using different statistical methods as well as rainfall-runoff models. Moreover, uncertainty is incorporated in the hydraulic model itself and flow conditions used.
\end{abstract}

Keywords: flood, modeling, uncertainty, digital elevation model, design discharges, hydraulic model

\section{Úvod}

Povodňové modelovanie, resp. povodňové mapy sú dôležitou súčast'ou analýzy a manažmentu povodňového rizika, pretože ich výsledkom je zobrazenie povodňového nebezpečenstva z hl'adiska híbky vody, rozsahu záplavy a rýchlosti prúdenia vody v zaplavenom území.

Podl'a EXCIMAP (2007) povodňové mapy spĺn̆ajú minimálne tri ciele manažmentu povodňových rizík, a to zabraňujú zvyšovaniu a výskytu nového rizika (plánovanie a výstavba), redukujú existujúce riziko a dajú sa prispôsobit' v súvislosti so zmenami rizikových faktorov. Ich primárne využitie je preto v tvorbe stratégií manažmentu povodňového rizika (prevencia, zníženie následkov, adaptácia), územnom plánovaní, manažmente krízových situácií, vo zvyšovaní povedomia verejnosti o povodňovom ohrození, či v poist'ovníctve.

Povodňové modelovanie môže byt' dynamické v čase a môže sa tiež líšit' z hl'adiska zložitosti použitých prístupov (Horritt, Bates, 2001, Puesch, Raclot, 2002, Matgen et al., 2007). Okrem toho údaje, ktoré vstupujú do modelu môžu podliehat' chybám, ktoré sa môžu výrazne menit' v čase a priestore. $\mathrm{V}$ dôsledku toho sa v posledných rokoch značná pozornost' venuje pochopeniu a odhadu týchto 
neistôt s ciel'om spresnit' a zlepšit' analýzy povodňového rizika (Dimitriadis et al., 2016, Teng et al., 2017, Petroselli, Vojtek, Vojteková, 2018).

Hlavné zdroje neistôt $\mathrm{v}$ povodňovom modelovaní je možné rozdelit' do nasledovných skupín (Bates, Pappenberger, Romanowicz, 2014):

- Chyby vo vstupných dátach modelu (digitálny model reliéfu (DMR), batymetria koryta, koeficienty drsnosti povrchu, vzdialenost' medzi priečnymi profilmi koryta, údaje o samotnom toku, brehových čiarach, prekážky na toku ako napr. mosty, atd'.).

- Chyby v odhade návrhových prietokov s rôznou dobou opakovania, resp. výpočte hydrogramu povodňovej vlny, či použití konkrétneho zrážkovo-odtokového modelu.

- Vol'ba hydraulického modelu (1D alebo 2D prístup) a podmienok prúdenia vody (ustálené alebo neustálené prúdenie).

Ciel’om článku je poukázat' na neistoty v povodňovom modelovaní (t.j. pri tvorbe povodňových máp), ktoré vyplývajú predovšetkým z použitia rôznych hydrologicko-hydraulických modelov a ich vstupných dát (s dôrazom na DMR).

\section{Neistoty vyplývajúce z digitálneho modelu reliéfu}

Údaje o topografii inundačných území vo forme DMR, resp. batymetrie koryta zohrávajú dôležitú úlohu v povodňovom modelovaní. Úlohou DMR je čo najpresnejšia reprezentácia priestorovej premenlivosti reliéfu. Existuje však viacero zdrojov nepresností pri tvorbe, či použití určitého DMR (Voženílek, 2002):

- Techniky tvorby DMR - výškopisné údaje na tvorbu DMR je možné získat' rôznymi spôsobmi, ktoré sa však lísia cenou, presnostou a dostupnost'ou: geodetické merania, laserové skenovanie (LiDAR), GPS/GNSS merania, fotogrametrické merania, digitalizácia vrstevníc, radarové záznamy, družicové záznamy a iné.

- Mierka mapy - so zmenšením mierky mapy dochádza ku generalizácii, kedy sa mení priebeh a krivost' vrstevníc alebo hustota výškových bodov. Z toho vyplýva, že čím menšia mierka (väčšia generalizácia), tým väčšie nepresnosti vznikajú pri vytváraní DMR (mapa 1).

- Výber typu DMR - ide o odlišnosti pri použití DMR typu grid (raster) alebo DMR typu TIN (vektor).

- Parametre DMR - priestorové rozlíšenie rastra má vplyv na kvalitu DMR, a tým aj na presnost' povodňového modelovania (Hengl, 2006).

Vysoké rozlíšenie DMR a topografické údaje s vysokou presnost'ou sú nevyhnutné pre simulácie zaplavenia vodou najmä na rovinatých územiach, resp. územiach s nízkym sklonom a komplexnou mikrotopografiou (Casas et al., 2006). $\mathrm{V}$ súčasnosti sú pre DMR s vysokým rozlíšením dostupné viaceré 
automatizovanejšie riešenia ich získania pomocou satelitných alebo leteckých platforiem prieskumu Zeme. Pre povodňové modelovanie sa osvedčili predovšetkým letecká stereofotogrametria (Vojtek, Vojteková, 2016) (mapa 1), laserové skenovanie LiDAR (Marks, Bates, 2000, Fewtrell et al., 2011) a radar so syntetickou apertúrou (SAR) (Matgen et al., 2011). Radarová interferometria, napr. Shuttle Radar Topography Mission (SRTM) alebo Advanced Spaceborne Thermal Emission and Reflection Radiometer (ASTER), môže tiež poskytovat' použitel'ný zdroj topografických údajov pre hydraulické modelovanie, avšak jej použitie je vhodné len vo vel'kých povodiach s vel'kou amplitúdou povodne (Wilson et al., 2007). Neistota $\mathrm{v}$ prípade DMR získaných metódami dial'kového prieskumu Zeme tak spočíva $\mathrm{v}$ použitej senzorovej technológii, nadmorskej výšky snímača počas letu, rozlíšenia získaných dát a kvality akéhokol’vek následného spracovania.

Mapa 1: Porovnanie DMR vytvoreného z rôznych podkladov: a) Základná mapa SR (1 : 10 000); b) Vodohospodárska mapa (1: 50 000); c) TIN vytvorený z bodového pol'a získaného leteckou stereofotogrametriou

Map 1: Comparison of DEMs created from various input data: a) Basic Map of the Slovak Republic (1 : 10 000); b) Water Management Map (1 : 50 000); TIN created based on photogrammetric point field

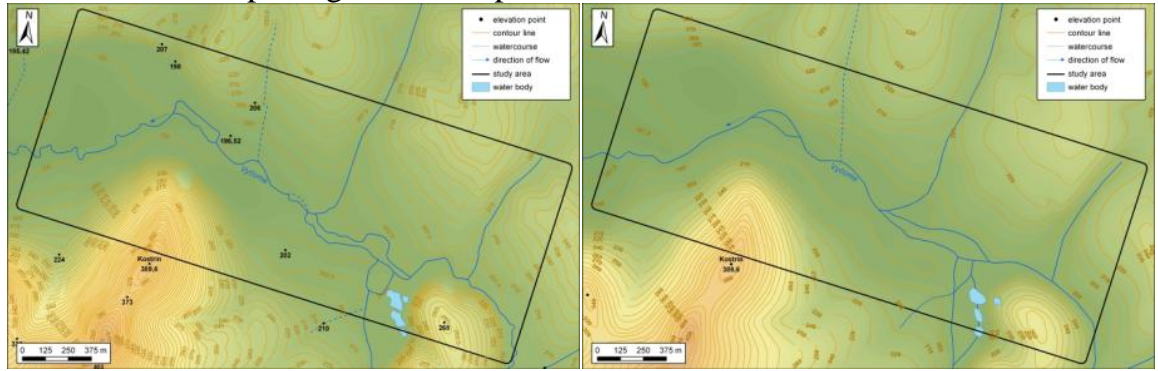

a)

b)

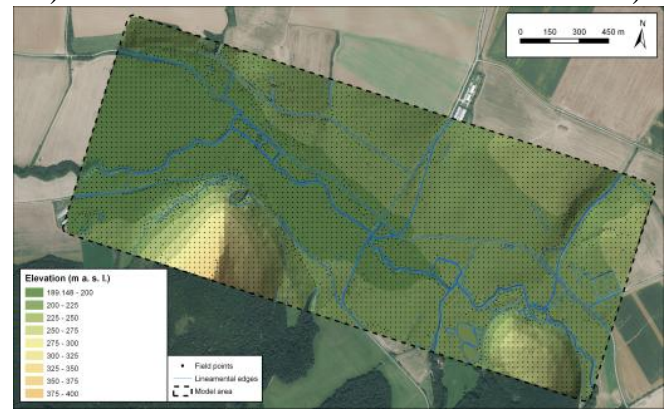

c)

Zdroj: Vojtek, Oláhová, Boltižiar (2013) 


\section{Neistoty v odhade N-ročných prietokov resp. hydrologickom modelovaní}

V rámci spracovania hydrologických podkladov pre povodňové modelovanie je riešenie odhadu N-ročných vôd jedným z kl'účových problémov. Metódy stanovenia návrhových prietokov (N-ročných maximálnych prietokov) môžeme všeobecne rozdelit' na priame a nepriame.

Pri odhade N-ročných vôd priamymi metódami, teda pre profily $\mathrm{s}$ vodomernou stanicou, sa stretávame s viacerými neistotami.

Prvou je neistota vyplývajúca $\mathrm{z}$ kvality podkladových údajov, $\mathrm{v}$ rámci ktorej sa musíme spoliehat' na údaje priamych pozorovaní. Podl'a Makel'a a kol. (2003) by mal byt' tento súbor neprerušený (homogénny) a dlhší ako 20 rokov. Na druhej strane Solín (2005) poukazuje na fakt, že na spol'ahlivý odhad 100-ročnej vody $\mathrm{v}$ určitej vodomernej stanici by bol potrebný 500 rokov dlhý pozorovacích rad, čo však nespíňa žiadna vodomerná stanica. Z toho dôvodu sa na odhad Nročných prietokov aplikujú štatistické metódy.

Použitie štatistických metód prináša aj štatistickú neistotu vyplývajúcu z ich podstaty. Ide predovšetkým o vplyv vol’by typu čiary prekročenia, výber metódy odhadu jej parametrov, vplyv dížky radu na odhad parametrov, vychýlenost' odhadov z krátkych radov pozorovaní, atd'. Z toho dôvodu je potrebné použit' viacero typov rozdelení a metód odhadu ich parametrov, ktoré umožnia vybrat' teoretickú čiaru prekročenia, ktorá najlepšie vyrovnáva empirickú čiaru prekročenia. Ako vyplýva z výsledkov viacerých štúdií, napr. Mitková, Kohnová, Pekárová (2004) alebo Vojtek (2014), výber metódy a jej následná štatistická analýza má významný vplyv na výsledné hodnoty návrhových prietokov (graf 1).

Graf 1: Porovanie empirickej čiary prekročenia a rôznych teoretických čiar prekročenia maximálnych prietokov na toku Vyčoma v stanici Hájovňa Slače Graph 1: Comparison of empirical and different theoretical lines of maximum discharges: Vyčoma stream (Hájovňa Slače gauging station)

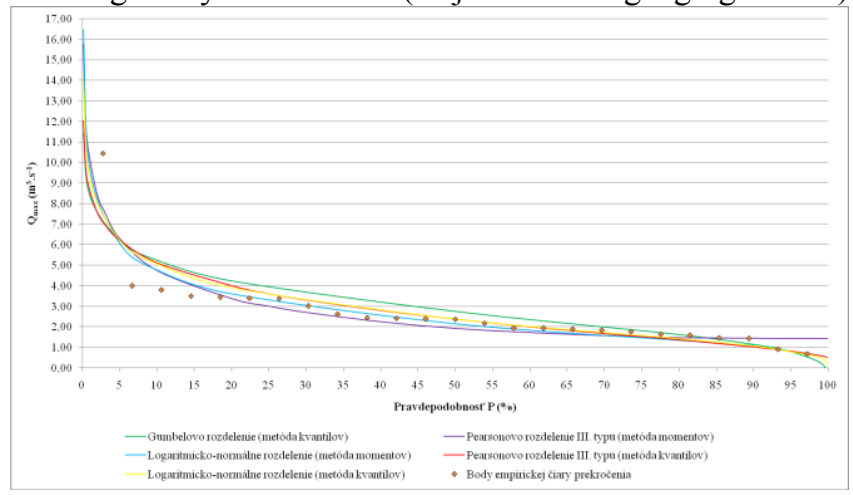

Zdroj: Vojtek (2014) 
Stanovenie N-ročných maximálnych prietokov mimo vodomerných staníc si vyžaduje použitie odlišných prístupov. Podla Solína (2006) sa odhad maximálnych prietokov uskutočňuje pomocou dvoch základných skupín metód.

Prvú skupinu tvoria zrážkovo-odtokové metódy. V súlade s Mosným (2002) môžeme v rámci zrážkovo-odtokových metód použit:

- metódu analógie,

- empirické vzt’ahy:

- regionálne (oblastné) vzorce,

- intenzitné vzorce,

- objemové vzorce,

- metódu SCS (Soil Conservation Service).

Zrážkovo-odtokové metódy všeobecne vychádzajú z údajov o zrážkach a fyzickogeografických atribútoch povodia. Ich štruktúra je $\mathrm{v}$ prípade rôznych empirických vzorcov vel'mi jednoduchá. Maximálny prietok je funkciou plochy povodia a koeficientov, ktorých vel'kost' závisí od fyzickogeografických atribútov povodia.

Regionálne metódy stanovenia N-ročných maximálnych prietokov použili napr. Kohnová, Szolgay (1995), Kohnová, Solín, Szolgay (2003) alebo Szolgay, Kohnová, Hlavčová (2003), ktorí však upozorn̆ujú na regionalizačnú neistotu vyplývajúcu z používania priestorových zovšeobecňovaní $\mathrm{v}$ prípade absencie priamych pozorovaní ako je napr. výber regionálnej jednotky a zaradenie povodia do nej. Kohnová et al. (2005) porovnávali viacero metód, pričom výsledky poukazujú na to, že tradičné regionálne metódy vykazujú o niečo väčšie prietoky ako iné štatistické metódy ako je napr. regionálna frekvenčná analýza.

Druhú skupinu tvoria štatistické metódy, ktoré sú založené na frekvenčnej analýze ročných maximálnych prietokov. Solín (2005) poukazuje na fakt, že hydrologické pozorovania sa vykonávajú na obmedzenom počte vodných tokov, ktorých pozorovacie rady sú relatívne krátke na vykonanie spol'ahlivého odhadu ročných maximálnych prietokov najmä s menšou pravdepodobnost'ou výskytu. $\mathrm{Z}$ toho dôvodu by sa mal odhad N-ročných maximálnych prietokov uskutočnit' regionálnou frekvenčnou analýzou, ktorá je založená na myšlienke, že ak frekvencie výskytu javov určitej vel'kosti sú si podobné, tak spoločná analýza dát povodí $\mathrm{s}$ rovnakou hydrologickou reakciou, než dát $\mathrm{z}$ jedného povodia, je opodstatnenejšia. Existuje viacero prístupov a metód regionálnej frekvenčnej analýzy (Zrinji, Burn, 1994, Bobée et al., 1996, Hosking, Wallis, 1997).

Stanovenie N-ročných maximálnych prietokov pomocou regionálnej frekvenčnej analýzy si vyžaduje riešenie troch hlavných problémov (Solín, 2006):

- identifikovanie fyzickogeografických regionálnych tried,

- výber regionálnej distribučnej funkcie a odhadu jej parametrov,

- odhad strednej hodnoty ročného maximálneho prietoku pre povodia bez hydrologických pozorovaní. 
Význam zrážkovo-odtokových modelov (hydrologické modelovanie) spočíva najmä $\mathrm{v}$ určení hydrologických parametrov ako vstupných dát pre hydraulické modelovanie. Zrážkovo-odtokové modely simulujú pomocou matematických výpočtov realitu zložitých procesov prebiehajúcich v povodí. Nezávisle na vel'kosti povodia sú tieto procesy definované klímou, topografiou, geologickými pomermi, pôdami, vegetáciou a využitím zeme. Matematický model zrážkovo-odtokového procesu predstavuje zjednodušený kvantitatívny vzt’ah medzi vstupnými a výstupnými veličinami určitého hydrologického systému. Ten je definovaný ako systém prevažne fyzikálnych procesov, pôsobiacich na vstupné premenné, ktoré potom transformuje do výstupných veličín. V matematickom modeli ide potom o algoritmus riešenia sústavy rovníc, ktoré popisujú štruktúru a chovanie systémov (Daňhelka a kol., 2003). Neistoty v zrážkovo-odtokových modeloch vyplývajú najmä $\mathrm{z}$ ich štruktúry a princípov fungovania, ktorých prehl'ad a klasifikáciu ponúka napr. Beven (2012) alebo Sitterson et al. (2017).

Z uvedeného je zrejmé, že určenie N-ročných vôd sa nedá považovat' za jednoznačný výpočtový postup s jednoznačným výsledkom. Je to úloha, ktorá sa dá riešit viacerými štatistickými a hydrologickými postupmi. Z hladiska praktickej použitel'nosti by sa mohli výsledky odhadu rôznymi metódami v princípe považovat' za rovnocenné za predpokladu, že boli dodržané podmienky správneho použivania jednotlivých metód. Ako dôsledok to znamená, že výslednú N-ročnú veličinu aj tak nakoniec musíme zvolit' zo spektra výsledkov použitých postupov, pričom tie môžu byt' aj značne rozdielne (Szolgay, Kohnová, Hlavčová, 2003).

\section{Neistoty v hydraulickom modelovaní}

Pri hydraulickom modelovaní je dôležitá v prvom rade vol'ba modelu. Pri povodňovom modelovaní, resp. tvorbe povodňových máp sú najčastejšie využívané jednorozmerné (1D) alebo dvojrozmerné (2D) hydraulické modely. Tie umožňujú modelovat' ustálené alebo neustálené prúdenie.

Ustálené prúdenie je teoreticky zjednodušený stav, ktorý nerešpektuje reálny čas, nesimuluje výšku vodnej hladiny v celom rozsahu povodňovej vlny, ale zameriava sa na odhad maximálnej výšky pre povodňové prietoky rôznej doby opakovania $\mathrm{v}$ priečnych profiloch vodného toku. Ustálené prúdenie je akceptovatel'né najmä v prípade prirodzene vzniknutých povodní, napr. topením snehu alebo dlhotrvajúcim dažd’om, kedy sa výška hladiny vzhl'adom na čas mení relatívne pomaly. Podl'a Solína a Martinčákovej (2007) sa takéto prúdenie nedá aplikovat' v prípade, že:

- pohyb povodňovej vlny je vel'mi rýchly,

- nastáva vzdutie hladiny $\mathrm{v}$ dôsledku prirodzených alebo umelých podmienok vytvorených na dolnom úseku, 
- závislost' medzi prietokom a výškou hladiny nie je jednoznačná (najmä na vel'kých tokoch s vel'mi malým sklonom).

Neustálené prúdenie nepočíta s konštantným povodňovým prietokom, ale $\mathrm{s}$ tým, že tento prietok sa s časom mení. Čo sa týka výpočtu, ide o náročnejšiu úlohu, kedy výpočet prebieha vo vopred stanovených časových úsekoch, v ktorých dochádza ku zmene vodných stavov a prietokov.

Princíp 1D hydraulických modelov (napr. HEC-RAS, MIKE 11, ISIS) spočíva $\mathrm{v}$ stanovení sústavy priečnych profilov, ktoré by mali byt' kolmé na smer prúdenia vodného toku, pričom výpočet výšky vodnej hladiny v určitom profile je založený na výške hladiny v predchádzajúcom profile. Tieto modely boli tradične parametrizované pomocou pozemných geodetických meraní priečnych profilov, ktoré sú kolmé na priebeh koryta vo vzdialenostiach medzi 100 a 1000 m (Bates, Pappenberger, Romanowicz, 2014). Takto namerané údaje sú presné v rozmedzí niekol'kých milimetrov v rámci horizontálnej i vertikálnej chyby. Na druhej strane sú tieto metódy drahé a časovo náročné, a preto sú často nahrádzané presnými DMR, na podklade ktorých sú automaticky vložené priečne profily vo zvolenom dížkovom intervale a šírke. Okrem parametrov koryta sa berú v úvahu aj rôzne prekážky (mosty alebo hrádze), ktoré majú vplyv na prietok a je možné ich zakomponovat' do samotného modelu. Pri použití presných vstupných dát, sú $1 \mathrm{D}$ hydraulické modely ustáleného prúdenia vhodnou vol'bou a dokážu s vysokou presnost'ou simulovat' potenciálnu povodňovú hrozbu najmä na lokálnej úrovni (Solín, Martinčáková, 2007). Výhody 1D hydraulických modelov sú predovšetkým v krátkom výpočtovom čase, menšej náročnosti na vstupné dáta, a preto je možné ich aplikovat' aj na dlhšie úseky vodných tokov. Nevýhodou je, že neposkytujú informácie o celkovom charaktere a smere prúdového pol'a alebo spôsobu obtekania jednotlivých prekážok (napr. budov), čo je dôležité najmä v zastavaných oblastiach (Valentová, Valenta, 2006).

2D hydraulické modely (napr. MIKE 21, LISFLOOD-FP, TELEMAC-2D, FLO-2D) sú podstatne náročnejšie na výkon hardvéru a tiež na vstupné dáta. Ich princíp spočíva $\mathrm{v}$ pokrytí celého záujmového územia trojuholníkovou alebo štvorcovou siet’ou. Vd'aka sieti výpočtových bodov v záujmovom území je možné získat' detailnú predstavu o jej plošnom rozdelení a o stanovených hydraulických premenných. 2D modely poskytujú okrem základných informácií o polohe hladiny aj d’alšie údaje, ktoré 1D modely neposkytujú. Sú to napr. informácie o celkovom charaktere prúdového pol'a, spôsobu obtekania jednotlivých prekážok, informácie o híbkach vody a o smeroch a vel'kosti rýchlostí v celom rozsahu modelovanej oblasti (Kozel, Fürst, 2001). 2D modely predstavujú prijatel'né východisko pri modelovaní prúdenia $\mathrm{v}$ zložitých priestorových podmienkach, kde je potreba hustej siete výpočtových bodov so stanovenými detailnými charakteristikami prúdenia. Takéto miesta sú najčastejšie tam, kde sa výrazne prejavuje priečny náklon hladiny, kde sú komplikované inundačné územia alebo v intravilánoch obcí, kde sú obtekané výrazné prekážky a objekty (Horritt, Bates, 2002). 
Výhodou väčšiny 1D a 2D hydraulických modelov je ich prepojitel'nost' na geografické informačné systémy (GIS), ktoré umožňujú prípravu vstupných dát pre samotné modelovanie (pre-processing) a po modelovaní, aj analýzy a vizualizácie (post-processing) (Zerger, Wealands, 2004).

Neistoty vyplývajúce $\mathrm{z}$ hydraulického modelovanie tak spočívajú najmä $\mathrm{v}$ aplikácii konkrétneho modelu $\mathrm{v}$ neadekvátnych podmienkach. Okrem toho je akceptovanie výsledkov modelovania podmienené dostatočnou kvalitou a presnost'ou vstupných dát, a to najmä DMR.

\section{Záver}

V posledných rokoch môžeme sledovat', aj v súvislosti s klimatickými zmenami, zvýšený výskyt a magnitúdu povodní, ktoré svojou ničivou silou spôsobujú značné materiálne škody. Na tento fakt zareagovala aj Európska únia vydaním smernice 2007/60/ES Európskeho parlamentu a Rady o hodnotení a manažmente povodňových rizík, ktorá sa stala základom pre zákon č. 7/2010 o ochrane pred povodňami v Slovenskej republike a jeho novele zákona č. 71/2015. Všetky tieto základné dokumenty stanovujú okrem iného aj vypracovanie máp povodňového ohrozenia, ktoré poskytnú informácie najmä o výške hladiny a rozsahu zaplaveného územia, ktorý zodpovedá maximálnym prietokom rôznej doby opakovania.

Malé povodia, resp. malé vodné toky sú z hl'adiska počtu potenciálne ohrozených obcí, často sa vyskytujúcich prívalových dažd’ov a slabej regulácie tokov relatívne najviac náchylné $\mathrm{k}$ vzniku povodní. Okrem toho je presnost' výsledkov získaných povodňovým modelovaním najväššia práve na lokálnej úrovni.

Proces tvorby máp povodňového ohrozenia, t.j. povodňové modelovanie, nie je jednoduchý a stretáva sa s viacerými neistotami, ktoré vyplývajú predovšetkým z použitia rôznych hydrologicko-hydraulických modelov a ich vstupných dát.

DMR, ako jeden z hlavných vstupov do hydraulického modelovania, by mal čo najpresnejšie reprezentovat' koryto a záplavové územie. V tejto súvislosti je potrebné klást' dôraz najmä na kvalitu vstupných údajov pre tvorbu DMR a výber priestorového rozlíšenia, t.j. DMR s vysokým rozlíšením by mali byt' uprednostňované $\mathrm{v}$ povodňovom modelovaní. Č́o sa týka odhadu N-ročných maximálnych prietokov s rôznou dobou opakovania, je lepšie porovnat' viacero metód, hoci výsledné hodnoty môžu byt' výrazne odlišné, a na základe ich porovnania zvolit' najvhodnejšiu metódu. Výber hydraulického modelu závisí tiež od finančných a časových možností a predovšetkým od špecifickosti hydraulickej úlohy, ktorá sa má vykonat'.

Nezanedbatel'né neistoty $\mathrm{v}$ povodňovom modelovaní možno hl'adat' aj $\mathrm{v}$ d'alších vstupných dátach, ktorým sa tiež v literatúre venuje značná pozornost'. Ide o koeficienty drsnosti povrchu (Dimitriadis et al., 2016), vzdialenost' medzi 
priečnymi profilmi koryta (Ali, Di Baldassarre, Solomatine, 2015), údaje o samotnom modelovanom toku, brehových čiarach, či prekážkach na toku ako sú mosty alebo hrádze (Altarejos-García et al., 2012), atd'.

Otázku, či hlavným zdrojom neistoty je bud' parametrizácia modelu alebo chyby súvisiace so vstupnými dátami, nie je možné l'ahko vyriešit', pretože tieto zdroje sú vzájomne prepojené a nemôžeme ani jeden z nich zanedbat'.

\section{Pod'akovanie}

Príspevok bol spracovaný v rámci projektu podporeného Univerzitnou grantovou agentúrou UKF v Nitre (UGA č. VIII/29/2017).

\section{Literatúra}

ALI, A. M. - DI BALDASSARRE, G. - SOlOMATINE, D. P. 2015. Testing different cross-section spacing in 1D hydraulic modelling: a case study on Johor River, Malaysia. In Hydrological Sciences Journal. ISSN 0262-6667, 2015, vol. 60, no. 2, pp. 351-360.

ALTAREJOS-GARCÍA, L. - MARTÍINEZ-CHENOLL, M. L. - ESCUDERBUENO, I. - SERRANO-LOMBILLO, A. 2012. Assessing the impact of uncertainty on flood risk estimates with reliability analysis using 1-D and 2-D hydraulic models. In Hydrology and Earth System Sciences. ISSN 1027-5606, 2012, vol. 16, pp. 1895-1914.

BATES, P. D. - PAPPENBERGER, F. - ROMANOWICZ, R. J. 2014. Uncertainty in Flood Inundation Modelling. In Beven, K., Hall, J. (eds.) Applied Uncertainty Analysis for Flood Risk Management, pp. 232-269. ISBN 978-1-84816-270-9.

BEVEN, K. J. 2012. Rainfall-Runoff Modelling: The Primer. 2nd ed. Hoboken: Wiley-Blackwell.

BOBÉE, B. - MATHIER, L. - PERRON, H. - TRUDEL, P. - RASMUSSEN, P. F. - CAVADIAS, G. - BERNIER, J. - NGUYEN, V. T. V. - PANDEY, G. ASHKAR, F. et al. 1996. Presentation and review of some methods for regional flood frequency analysis. In Journal of Hydrology. ISSN 0022-1694, 1996, vol. 186, no. 1-4, pp. 63-84.

CASAS, A. - BENITO, G. - THORNDYCRAFT, V. R. - RICO, M. 2006. The topographic data source of digital terrain models as a key element in the accuracy of hydraulic flood modelling. In Earth Surface Processes and Landform. ISSN 1096-9837, 2006, vol. 31, no. 4, pp. 444-456.

DAŇHELKA, J. - KREJČÍ, J. - ŠÁLEK, M. - ŠERCL, P. - ZEZULÁ, J. 2003. Posouzeni vhodnosti aplikace srážko-odtokových modeli̊ s ohledem na simulaci povodñových stavů pro lokality na územi ČR. Praha: ČZÚ, ČHMÚ, 2003. 220 s. ISBN 80-86690-03-2. 
DIMITRIADIS, P. - TEGOS, A. - OIKONOMOU, A. - PAGANA, V. KOUKOUVINOS, A. - MAMASSIS, N. - KOUTSOYIANNIS, D. EFSTRATIADIS, A. 2016. Comparative evaluation of 1D and quasi- 2D hydraulic models based on benchmark and real-world applications for uncertainty assessment in flood mapping. In Journal of Hydrology. ISSN 00221694, vol. 534, pp. 478-492.

EXCIMAP. 2007. Handbook on Good Practices for Flood Mapping in Europe. Emmeloord: Drukkerij Feiko Stevens.

FEWTRELL, T. J. - DUNCAN, A. - SAMPSON, C. C. - NEAL, J. C. - BATES, P. D. 2011. Benchmarking urban flood models of varying complexity and scale using high resolution terrestrial LiDAR data. In Physics and Chemistry of the Earth. ISSN 1474-7065, 2011, vol. 36, no. 7-8, pp. 281-291.

HENGL, T. 2006. Finding the right pixel. In Computers \& Geosciences. ISSN 0098-3004, 2006, vol. 32, no. 9, p. 1283-1298.

HORRITT, M. S. - BATES, P. D. 2001. Predicting floodplain inundation: rasterbased modelling versus the finite-element approach. In Hydrological Processes. ISSN 1099-1085, 2001, vol. 15, no. 5, pp. 825-842.

HORRITT, M. S. - BATES, P. D. 2002. Evaluation of 1D and 2D Numerical Models for Predicting River Flood Inundation. In Journal of Hydrology. ISSN 0022-1694, 2002, vol. 268, no. 1-4, pp. 87-99.

HOSKING, J. R. - WALLIS, J. R. 1997. Regional Frequency Analysis. An Approach Based on L-moments. Cambridge: Cambridge University Press, 1997. $220 \mathrm{p}$.

KOHNOVÁ, S. - SZOLGAY, J. 1995. K používaniu Dubovho vzorca pre výpočet maximálneho storočného špecifického odtoku na malých povodiach Slovenska. In Vodohospodársky časopis. roč. 43, č. 1, s. 3-27.

KOHNOVÁ, S. - SOLÍN, L. - SZOLGAY, J. 2003. Regionálna analýza maximálnych prietokov. In Životné prostredie. ISSN 0044-4863, 2003, roč. 37, 2003, č. 6, s. 318-324.

KOHNOVÁ, S. - KRIEGEROVÁ, I. - PODOLINSKÁ, J. - SZOLGAY, J. HLAVČOVÁ, K. 2005. Regional Methods for Design Flood Computation in Slovakia (Review and Comparison). In Ninth International Symposium on Water Management and Hydraulic Engineering. Ottenstein, pp. 369-376.

KOZEL, K. - FÜRST, J. 2001. Numerické metody řěsení problémů prouděni I. Praha: ČVUT, 2001. 64 s. ISBN 80-01-02384-2.

MAKEL, M. - TURBEK, J. - PODOLINSKÁ, J. - ŠKODA, P. 2003. Stanovenie $N$-ročných prietokov a N-ročných prietokových vín na väčšich tokoch (Odvetvová technická norma MŽP SR 3112-1:03). Bratislava: Ministerstvo životného prostredia SR.

MARKS, K. - BATES, P. D. 2000. Integration of high-resolution topographic data with floodplain flow models. In Hydrological Processes. ISSN 1099-1085, vol. 14, no. 11-12, pp. 2109-2122. 
MATGEN, P. - SCHUMANN, G. - HENRY, J. B. - HOFFMANN, L. PFISTER, L. 2007. Integration of SAR-derived inundation areas, high precision topographic data and a river flow model toward real-time flood management. In International Journal of Applied Earth Observation and Geoinformation. ISSN 0303-2434, 2007, vol. 9, no. 3, pp. 247-263.

MATGEN, P. - HOSTACHE, R. - SCHUMANN, G. - PFISTER, L. HOFFMANN, L. - SAVENIJE, H. H. G. 2011. Towards an automated SARbased flood monitoring system: Lessons learned from two case studies. In Physics and Chemistry of the Earth. ISSN 1474-7065, 2011, vol. 36, no. 7-8, pp. 241-252.

MITKOVÁ, V. - KOHNOVÁ, S. - PEKÁROVÁ, P. 2004. Porovnanie odhadov maximálnych sezónnych prietokov $\mathrm{v}$ profile Dunaj- Bratislava. In Acta Hydrologica Slovaca. ISSN 1335-6291, 2004, roč. 5, č. 1, s. 34-41.

PETROSELLI, A. - VOJTEK, M. - VOJTEKOVÁ, J. 2018. Flood mapping in small ungauged basins: A comparison of different approaches for two case studies in Slovakia. In Hydrology Research. DOI: 10.2166/nh.2018.040.

PUECH, C. - RACLOT, D. 2002. Using geographical information systems and aerial photographs to determine water levels during floods. In Hydrological Processes. ISSN 1099-1085, vol. 16, pp. 1593-1602.

SITTERSON, J. - KNIGHTES, C. - PARMAR, R. - WOLFE, K. - MUCHE, M. - AVANT, B. 2017. An Overview of Rainfall-Runoff Model Types. Washington: Environmental Protection Agency, 2017. 29 p.

SOLÍN, L. 2005. Povodne - odhad ich vel'kostí pre malé povodia Slovenska metódou regionálnej frekvenčnej analýzy. In Geografický časopis. ISSN 00167193,2005 , roč. 57 , č. 4 , s. 287-307.

SOLÍN, L. 2006. Odhad N-ročných maximálnych prietokov regionálnou frekvenčnou analýzou. In Geographia Slovaca. ISSN 1210-3519, 2006, roč. $23,68 \mathrm{~s}$.

SOLÍN, L. - MARTINČÁKOVÁ, M. 2007. Niekol'ko poznámok k metodológii tvorby povodňových máp Slovenska. In Geografický časopis. ISSN 00167193, 2007, roč. 59, č. 2, s. 131-138.

SZOLGAY, J. - KOHNOVÁ, S. - HLAVČOVÁ, K. 2003. Neistoty určovania návrhových prietokov. In Životné prostredie. ISSN 0044-4863, 2003, roč. 37, č. 4. s. 194-199.

TENG, J. - JAKEMAN, A. J. - VAZE, J. - CROKE, B. F. W. - DUTTA, D. KIM, S. 2017. Flood inundation modelling: A review of methods, recent advances and uncertainty analysis. In Environmental Modelling \& Software. ISSN 1364-8152, 2017, vol. 90, pp. 201-216.

VALENTOVÁ, J. - VALENTA, P. 2006. Vliv prostorové schematizace na kvalitu numerického modelování proudění vody při povodních. In Journal of Hydrology and Hydromechanics. ISSN 0042-790X, 2006, vol. 54, no. 1, pp. 58-70.

VOJTEK, M. 2014. Estimation of N-Year Maximum Discharges for the Vyčoma 
Stream (Hájovňa Slače Profile). In Scientia iuvenis : Book of Scientific Papers. Nitra: CPU, 2014. ISBN 978-80-558-0650-1, pp. 279-288.

VOJTEK, M. - VOJTEKOVÁ, J. 2016. Flood hazard and flood risk assessment at the local spatial scale: a case study. In Geomatics, Natural Hazards and Risk. ISSN 1947-5713, 2016, vol. 7, no. 6, pp. 1973-1992.

VOJTEK, M. - OLÁHOVÁ, J. - BOLTIŽIAR, M. 2013. Vertical Accuracy Assessment of Digital Terrain Models Derived from Topographic Maps. In Scientia iuvenis 2013. Nitra: CPU, 2013. pp. 289-296.

VOŽENÍLEK, V. 2002. Vliv vyjádření reliéfu na výsledky modelování prostorových jevů. In Geografické informácie. ISBN 80-8050-542-X, 2002, roč. 7, č. 1, s. 321-328.

WILSON, M. D., BATES, P. D., ALSDORF, D. - Forsberg, B. - HORRITT, M. MELACK, J. - FRAPPART, F. - FAMIGLIETTIAL, J. 2007. Modeling largescale inundation of Amazonian seasonally flooded wetlands. In Geophysical Research Letters. ISSN 1944-8007, 2007, vol. 34, no. 15.

ZERGER, A. - WEALANDS, S. 2004. Beyond Modelling: Linking models with GIS for Flood Risk Management In Natural Hazards. ISSN 1573-0840, 2004, vol. 33, no. 2, pp. 191-208.

ZRINJI, Z. - BURN, D. H. 1994. Flood frequency analysis for ungauged sites using a region of influence approach. In Journal of Hydrology. ISSN 00221694, 1994. vol. 153, no. 1-4, pp. 1-21.

\section{UNCERTAINTIES IN FLOOD MODELING}

\section{Summary}

In recent years, an increased occurrence and magnitude of floods, which is also associated with the ongoing climate change, have caused considerable material damage. This fact has also been addressed by the European Union through the adoption of the Directive 2007/60/EC of the European Parliament and of the Council on the Assessment and Management of Flood Risks which has become the basis for Act no. 7/2010 on flood protection in the Slovak Republic and its amendment Act no. 71/2015. All these basic documents require, besides other measures, the creation of flood hazard maps that provide information, especially, on the water level and flood extent corresponding to the maximum discharges with different return periods.

Small basins or small watercourses are relatively the most vulnerable to floods in terms of the number of potentially endangered municipalities, occurrence of torrential rains and poor regulation of watercourses. In addition, the accuracy of the results obtained by flood modeling is much better, especially, at the local scale.

The creation of flood maps encounters a number of uncertainties that arise from the use of different hydrologic-hydraulic models and their input data. 
Digital elevation model (DEM), as one of the major inputs to hydraulic modeling, should represent the channel and floodplain as accurately as possible. In this context, emphasis should be placed on the quality of the input data for DEM creation, selection of the interpolation method and spatial resolution, i.e. highresolution DEMs should be favored in flood modeling. With regard to the estimation of T-year maximum discharges with different return periods, it is better to compare several methods, although the resulting design discharges may be significantly different, and based on their comparison, we should choose the most appropriate method. The choice of the hydraulic model depends mainly on the financial and time possibilities of the modeler as well as specificity of the hydraulic task to be performed.

Uncertainties in flood modeling can be also found in other input data, which is also being given a considerable attention in scientific literature. These uncertainties are represented by the roughness coefficients (Dimitriadis et al., 2016), cross-section spacing (Ali, Di Baldassarre, Solomatine, 2015), data on the modeled stream centreline, river banks or hydraulic structure along the reach such as bridges (Altarejos-García et al., 2012), etc.

The question of whether the main source of uncertainty is either the model parameterization or errors associated with model input data cannot be resolved easily because these resources are interconnected and neither of them can be neglected.

\section{Mgr. Matej Vojtek, PhD.}

Katedra geografie a regionálneho rozvoja FPV UKF v Nitre

Trieda A. Hlinku 1, 94974 Nitra

E-mail: mvojtek@ukf.sk 